\title{
Changes in chemical properties of distrophic Red Latosol as result of swine wastewater application
}

\author{
Juarez R. Cabral ${ }^{1}$, Paulo S. L. de Freitas ${ }^{2}$, Roberto Rezende ${ }^{3}$, Antonio S. Muniz ${ }^{4}$ \& Altair Bertonha ${ }^{5}$
}

${ }^{1}$ PGA/UEM. Maringá, PR. E-mail: jucacabral@yahoo.com.br

2 DAG/UEM. Maringá, PR. E-mail: pslfreitas@uem.br (Autor correspondente)

${ }^{3}$ DAG/UEM. Maringá, PR. E-mail: rrezende@uem.br

${ }^{4}$ DAG/UEM. Maringá, PR. E-mail: asmuiz@uem.br

${ }^{5}$ DAG/UEM. Maringá, PR. E-mail: abertonha@uem.br

\section{Key words:}

effluent

environmental impact

leaching

\begin{abstract}
A B S T R A C T
Swine wastewater (SW) has characteristics that allow its disposal in the soil as a fertilizer. This is an alternative in order not to accumulate this material in the farm as well as it provides savings with mineral fertilizers. The aim of this study was to evaluate the effect of applying swine wastewater on the chemical properties of a distrophic Red Latosol for two seasons. The experiment was carried out under field conditions with treatments defined as $\mathrm{T}_{0}=0$ (control), $\mathrm{T}_{1}=150, \mathrm{~T}_{2}=300, \mathrm{~T}_{3}=450, \mathrm{~T}_{4}=600, \mathrm{~T}_{5}=750 \mathrm{~m}^{3} \mathrm{ha}^{-1}$ of $\mathrm{SW}$ applied during the crop cycle of elephant grass. SW application contributed to the increase of magnesium and phosphorus and the reduction of soil aluminum in the first season. As for the second season when compared to the first one, there were reductions in $\mathrm{K}, \mathrm{Ca}$, and $\mathrm{P}$ concentrations. Hence applications of SW did not contribute to the increase in concentration of elements in the soil.
\end{abstract}

Palavras-chave:

efluente

impacto ambiental

lixiviação

\section{Alterações nas propriedades químicas de Latossolo Vermelho distrófico pela aplicação de água residuária de suinocultura}

\begin{abstract}
R E S U M O
A água residuária de suinocultura (ARS) possui características que possibilitam sua disposição no solo, como fertilizante. Esta é uma alternativa para o não acúmulo desse material na propriedade, além de proporcionar redução de custos com fertilizantes minerais. O objetivo do trabalho foi avaliar o efeito da aplicação, em duas épocas, de água residuária de suinocultura sobre as propriedades químicas de um Latossolo Vermelho distrófico. O experimento foi realizado em condições de campo, com os tratamentos definidos como segue: $\mathrm{T}_{0}=0$ (testemunha), $\mathrm{T}_{1}=150$, $\mathrm{T}_{2}=300, \mathrm{~T}_{3}=450, \mathrm{~T}_{4}=600, \mathrm{~T}_{5}=750 \mathrm{~m}^{3} \mathrm{ha}^{-1}$ de ARS, aplicados durante o ciclo da cultura do capim elefante. A aplicação de ARS contribuiu para o aumento do magnésio e do fósforo e a diminuição do alumínio no solo na primeira época; na segunda época, quando comparada com a primeira, ocorreram reduções na concentração de $K$, $\mathrm{Ca}$, e P; portanto, as aplicações de ARS não contribuíram para o aumento da concentração dos elementos no solo.
\end{abstract}

\section{INTRODUCTION}

The inclusion of industry in the swine productive process contributed to swine breeding improvement and the technification of the management system by using high technology in the fields of nutrition and health, consequently, the scale production increased, resulting in a large amount of wastewater as a side effect. Due to its polluting potential, the waste requires specific treatments established by environmental protection regulations, which might become limiting in some situations given the inappropriate training of the producers to manage such waste.

Despite the polluting potential of swine wastewater (SW), it has macro and micronutrients such as nitrogen, phosphorus, potassium, calcium, magnesium, iron, zinc, copper, and others that might contribute to the reduction of fertilizer application in crops.
Studies have focused the effect on the soil and plant with several remarks by various authors, as Bosco et al. (2008) evaluated the chemical changes of a distrophic Purple Latosol in the West of Paraná State as a result of the application of SW for eight consecutive years at a rate of $99 \mathrm{Mg} \mathrm{ha}^{-1}$ per year. Results showed that SW application increased calcium concentration in the soil from 641.3 to $1242.5 \mathrm{mg} \mathrm{L}^{-1}$ in the $0-30 \mathrm{~cm}$ layer while magnesium concentration increased from 243.1 to 449.7 $\mathrm{mg} \mathrm{L}^{-1}$. Phosphorus concentration, which was $33.7 \mathrm{mg} \mathrm{L}^{-1}$ in the $0-30 \mathrm{~cm}$ layer and $3.8 \mathrm{mg} \mathrm{L}^{-1}$ in the 30-60 layer before SW application, increased to $51.1 \mathrm{mg} \mathrm{L}^{-1}(0-30 \mathrm{~cm})$ and $5.4 \mathrm{mg} \mathrm{L}^{-1}$ (30-60 cm) after application.

On the other hand Aguiar et al. (2006) reported nutrient loss through leaching (especially phosphorus) after cattle waste and rice straw application. The authors also observed that the presence of organic matter as cattle manure favored nutrient leaching. 
Caovilla et al. (2005), studying the percolation of nutrients in soil columns planted with soybeans and irrigated with swine wastewater, observed that nitrate presented greater mobility in the leaching process, followed by the concentration of total salts and later potassium proportionally to the evaluated treatments. The treatment that presented $75 \%$ of wastewater had the highest concentrations of nitrate, potassium, and salts among leached substances.

Barros et al. (2005), evaluating soil chemical characteristics as a function of adding swine wastewater, observed that $\mathrm{pH}$ decreased with increase in temperature up to $30{ }^{\circ} \mathrm{C}$ during 96 days of incubation in soils with and without SW.

Queiroz et al. (2004) applied SW at a rate of $800 \mathrm{~kg}$ of $\mathrm{DBO}_{5}$ $\mathrm{ha}^{-1} \mathrm{~d}^{-1}$ for four months in a Red-Yellow Latosol planted with grass (quicuio da Amazônia, brachiaria, coastcross, and tifton 85) and verified that the application did not affect the grass development. Available P, exchangeable K and Na concentrations increased and exchangeable zinc accumulated in soil indicating potential risk of contamination. The authors concluded that, although large amounts of macro and micronutrients were incorporated with the application of SW, there was no saturation of the soil exchange complex and the cation exchange capacity (CEC) increased.

Freitas et al. (2004) applied SW depths, corresponding from 0 to 1.5 times the evapotranspiration of the reference crop $\left(\mathrm{ET}_{0}\right)$, to corn silage and concluded that SW application increased plant height, ear index and corn ear weight.

The knowledge about what enables the use of residual water generated during productive processes in agricultural areas reducing the environmental impact and increasing yield is extremely important. Therefore this study is aimed to evaluating the impact of different rates of swine wastewater application on soil chemical characteristics.

\section{Material ANd Methods}

The experiment was carried out at Campus do Arenito - Maringá State University in Cidade Gaúcha, Paraná State, latitude $23^{\circ} 22^{\prime} 30^{\prime \prime}$ South, longitude $52^{\circ} 56^{\prime} 00^{\prime \prime}$ West and mean altitude of $404 \mathrm{~m}$. The soil is classified as distrophic Red Latosol with medium texture, originated from Caiuá sandstone. Soil gradation is $830 \mathrm{~g} \mathrm{~kg}^{-1}$ sand, $10 \mathrm{~g} \mathrm{~kg}^{-1}$ silt, and $160 \mathrm{~g} \mathrm{~kg}^{-1}$ clay. The planting of elephant grass was carried out in two seasons, $01 / 05 / 2009$ and $01 / 05 / 2010$, in furrows without fertilization. The grass was planted in three rows spaced at $1.10 \mathrm{~m}$. Applied treatments were defined through raffle (for each of the plots of the blocks). Treatments were as follows: $\mathrm{T}_{0}-$ Control (without SW application), $\mathrm{T}_{1}$ to $\mathrm{T}_{5}$ with application of swine wastewater at the rates $\mathrm{T}_{1}-150 \mathrm{~m}^{3} \mathrm{ha}^{-1}, \mathrm{~T}_{2}-300 \mathrm{~m}^{3} \mathrm{ha}^{-1}, \mathrm{~T}_{3}-450 \mathrm{~m}^{3} \mathrm{ha}^{-1}$, $\mathrm{T}_{4}-600 \mathrm{~m}^{3} \mathrm{ha}^{-1}$, and $\mathrm{T}_{5}-750 \mathrm{~m}^{3} \mathrm{ha}^{-1}$. The experimental design was completely randomized blocks with four replications.

An irrigation system through conventional sprinkling was installed at the experimental area aiming to keep water content under appropriate conditions for crop development in the soil so that water was not a limiting factor.
Irrigation was performed according to climatologic water balance and evapotranspiration of the reference crop calculated using the Penman-Monteith (Allen et al., 2005) equation and data from the automatic meteorological station, which was located $50 \mathrm{~m}$ from the experimental area.

Wastewater was sampled in all applications and sent to the Laboratory of Characterization and Residues Recycling of the Agronomy Department of Maringá State University located in Maringá, PR. For SW characterization, $\mathrm{Ca}, \mathrm{N}, \mathrm{P}, \mathrm{K}, \mathrm{Mg}$, and $\mathrm{N}_{\text {total }}$ were analyzed (Table 1). Ca and $\mathrm{Mg}$ values were determined by atomic absorption spectroscopy, $\mathrm{K}$ was determined by flame emission photometry, $\mathrm{P}$ values were determined by calorimetry using the method of ammonium molybdate, and the values of $\mathrm{N}$ by the Kjeldahl method.

Table1. Characteristics of swine wastewater in each application

\begin{tabular}{crrrrrr}
\hline \multirow{2}{*}{ Date } & $\mathbf{C a}$ & $\mathbf{M g}$ & $\mathbf{K}$ & $\mathbf{P}$ & $\mathbf{N a}$ & \multicolumn{1}{c}{$\mathbf{N}$} \\
\cline { 2 - 7 } $\mathbf{m g ~ L}^{-1}$ & \multicolumn{7}{c}{$\mathbf{m g}^{-1}$} & & & \\
$02 / 23 / 2009$ & 212 & 31 & 108 & 73 & 47 & 266 \\
$03 / 14 / 2009$ & 211 & 53 & 253 & 168 & 99 & 749 \\
$03 / 28 / 2009$ & 166 & 54 & 279 & 171 & 104 & 786 \\
$04 / 03 / 2009$ & 332 & 121 & 507 & 137 & 148 & 1.183 \\
$04 / 27 / 2009$ & 405 & 124 & 474 & 127 & 146 & 1.299 \\
$03 / 09 / 2010$ & 325 & 80 & 220 & 107 & 143 & 1.078 \\
$03 / 26 / 2010$ & 190 & 123 & 244 & 120 & 145 & 927 \\
$04 / 09 / 2010$ & 228 & 81 & 199 & 90 & 140 & 837 \\
$04 / 16 / 2010$ & 358 & 89 & 224 & 111 & 151 & 1.375 \\
$04 / 30 / 2010$ & 358 & 89 & 224 & 111 & 151 & 1.375 \\
\hline
\end{tabular}

To evaluate the effect of applying SW, disturbed soil samples were collected of all plots prior to elephant grass planting and after harvest at layers 0-0.5, 5-10, 10-20, 10-20, 20-40, and $40-60 \mathrm{~cm}$. To study the effect of SW application in soil, $\mathrm{pH}, \mathrm{Al}, \mathrm{Ca}, \mathrm{Mg}, \mathrm{K}, \mathrm{P}$, and $\mathrm{C}$ analysis were performed. Results were subjected to variance analysis and significant variables were submitted to mean comparison by the Tukey test at 0.05 probability.

Five applications were carried out manually using $10 \mathrm{~L}$ plastic flasks, in which each application corresponded to a rate of $150 \mathrm{~m}^{3} \mathrm{ha}^{-1}$ : treatment $1\left(\mathrm{~T}_{1}\right)$ received SW application only once $\left(150 \mathrm{~m}^{3} \mathrm{ha}^{-1}\right)$ while treatment $2\left(\mathrm{~T}_{2}\right)$ received two applications $\left(300 \mathrm{~m}^{3} \mathrm{ha}^{-1}\right)$, up to treatment $5\left(\mathrm{~T}_{5}\right)$, which received five applications $\left(750 \mathrm{~m}^{3} \mathrm{ha}^{-1}\right)$. At the time of application the effluent was carefully distributed in order to be uniform on the soil surface of the experimental plot.

The magnitude of rainfall during the experiment period and swine wastewater application dates are given in Figure 1.

\section{Results AND Discussion}

The $\mathrm{pH}$ values of the soil profile prior to treatment application were not statistically different at 0.05 probability, and the $\mathrm{pH}$ values for the second season were lower than those in the first season (Table 2, Figure 2A)

Wastewater application in the first season of elephant grass planting did not alter soil $\mathrm{pH}$. However, $\mathrm{pH}$ decreased after 


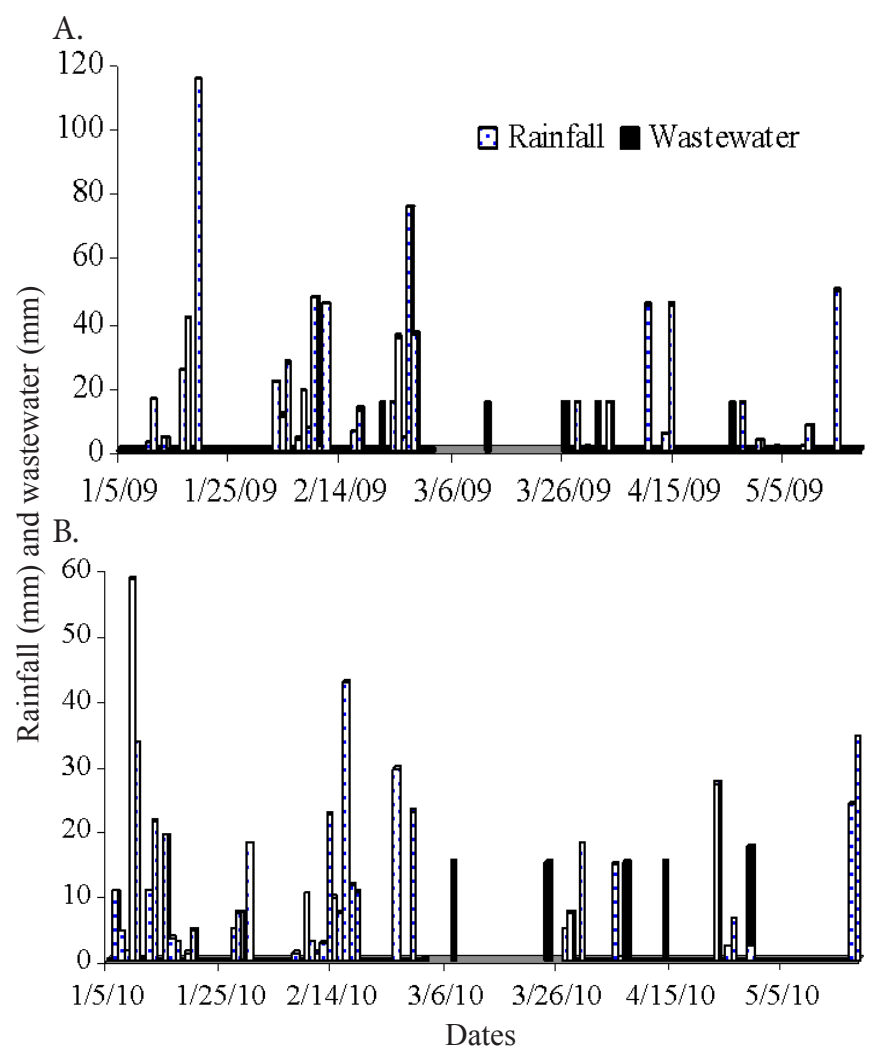

Figure 1. Rainfall during the experiment and swine wastewater applied in the first (A) and second (B) seasons

Table 2. Mean values of soil $\mathrm{pH}$ for both seasons

\begin{tabular}{cccc}
\hline Season & Collecting season & \multicolumn{2}{c}{$\mathbf{p H}$} \\
1 & Before planting & 5.97 & $\mathrm{~A}$ \\
1 & After harvest & 5.79 & $\mathrm{~A}$ \\
2 & After harvest & 5.39 & $\mathrm{~B}$ \\
2 & Before planting & 5.20 & $\mathrm{C}$ \\
\hline
\end{tabular}

treatment application in the second season as compared to the first. The $\mathrm{pH}$ values for the first season before and after treatment applications were 5.97 and 5.79 respectively whereas for the second they were respectively 5.20 and 5.39 (Table 2).

This reduction might have occurred due to the organic waste mineralization and the release of organic acid thus decreasing $\mathrm{pH}$ according to Guedes et al. (2006). Bezerra et al. (2006), studying the application of sewage sludge for reforestation of degraded areas, found that five rates $(0,2.85,5.7,11.4$, and 22.8 $\mathrm{t} \mathrm{ha}^{-1}$, without lime) applied to the soil reduced $\mathrm{pH}$ significantly. The results found in this study are in accordance with Smanhotto (2008) and Caovilla et al. (2005).

It was not possible to adjust the regression equation to the soil $\mathrm{pH}$, since the equations are not significant at the $5 \%$ probability level (Figure 2B). Similar to the first season, SW rates applied did not affect soil pH (Figures 2B and 2C).

Results obtained in this study confirm those obtained by Duarte et al. (2008), who evaluated the effect of applying treated domestic wastewater and water from public supply to pepper crop and concluded that the use of wastewater did not alter soil $\mathrm{pH}$ significantly.
A.
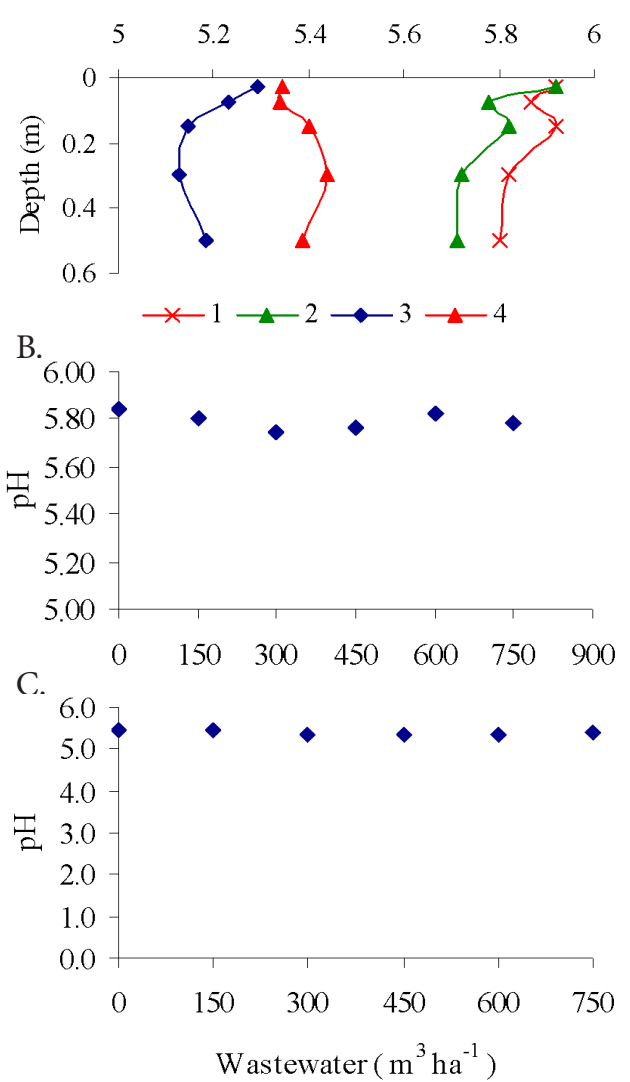

1 and 2 before planting and after harvest, first season. 3 and 4 before planting and after harvest, second season.

Figure 2. Soil $\mathrm{pH}$ values as a function of depth $(\mathrm{A})$ and as a function of wastewater rate for the first season (B) and second season $(\mathrm{C})$

Ca values in soil presented differences with treatment application, which were statistically significant at 0.05 probability (Table 3 ).

The mean $\mathrm{Ca}$ value in soil before treatment application was $0.955 \mathrm{cmol} \mathrm{dm}_{c}^{-3}$ and after application $0.715 \mathrm{cmol}_{c} \mathrm{dm}$ ${ }^{3}$. For the first season, Ca values in the soil profile prior to treatment application were not statistically different at 0.05 probability level. However, the Ca concentration was not reduced only in the $0-5 \mathrm{~cm}$ layer (Figure $3 \mathrm{~A}$ ). After treatment application, results were different from those observed by Freitas et al. (2004), who reported an increase in Ca concentration from 0.175 to $1.62 \mathrm{cmol}_{c} \mathrm{dm}^{-3}$ when applying SW to corn crop.

In the second season prior to treatment application, soil calcium concentration was 0.854 and after applications 0.672 $\mathrm{cmol}_{c} \mathrm{dm}^{-3}$ (Table 3). Differences in these Ca concentration values were significant at 0.05 by the Tukey test. A possible

Table 3. Mean values of $\mathrm{Ca}$ in soil for both seasons

\begin{tabular}{cccc}
\hline Season & Collecting season & \multicolumn{2}{c}{ Ca $\left(\mathbf{c m o l}_{\mathbf{c}} \mathbf{~ d m}^{-3}\right)$} \\
1 & Before planting & 0.955 & $\mathrm{~A}$ \\
2 & Before planting & 0.854 & $\mathrm{~B}$ \\
1 & After harvest & 0.715 & $\mathrm{C}$ \\
2 & After harvest & 0.672 & $\mathrm{C}$ \\
\hline
\end{tabular}


explanation for this is the imbalance between the calcium source $($ soil + SW) and the drain, and the amount of calcium removed from the plant.

The results obtained are in disagreement with those found by Queiroz et al. (2004), who did not observe variations in soil Ca contents when applying SW. Also, results differ from those reported by Bosco et al. (2008), who verified that the SW application at a rate of $99 \mathrm{t} \mathrm{ha}^{-1}$ per year, during eight consecutive years, in a distrophic Dusky Red Latosol (West of Paraná State) increased calcium concentration from 0.001 to $2.78 \mathrm{cmol}_{\mathrm{c}} \mathrm{dm}^{-3}$ in the $0-30 \mathrm{~cm}$ layer. Corn was grown during summer cropping season, and wheat and corn during winter. Also, Melo et al. (2006) increased calcium concentration in soil applying wastewater from a cassava industry.

In the second season a quadratic behavior for $\mathrm{Ca}$ rates in soil (Figure 3C) was observed, differently from the first season, in which Ca concentration presented linear behavior with SW rates, as given by Figure $2 \mathrm{~B}$.

In relation to $\mathrm{Ca}$ there was a significant increase of its contents with the rates from the first to the second season. However, there was a significant decrease among contents before and after harvest for both seasons (Table 3). It is assumed that SW added Ca to the soil, explained its composition (Table 1), the content in soil increased with rates, and higher content was observed in the second season compared to the first. On the other hand, the reduction of Ca contents before and after harvest in each season might be associated to the imbalance source/drain: the source represented by soil $\mathrm{Ca}$ and added by SW and the drain represented by the removal of Ca by the plants.

The Ca values in the soil profile prior to SW application differ statistically. Although, after treatment application, statistical differences of $\mathrm{Ca}$ concentration values occurred in the $0-5 \mathrm{~cm}$ layer to the 40-60 cm layer (Figure 3A).

For the first season, Al values showed differences statistically significant at 0.05 probability level with treatment application. The $\mathrm{Al}$ mean value in soil before applying treatments was $0.078 \mathrm{cmol}_{\mathrm{c}} \mathrm{dm}^{-3}$ and after treatment application $0.039 \mathrm{cmol}_{\mathrm{c}}$ $\mathrm{dm}^{-3}$ (Table 4). The Al values in soil profile prior to treatment application were not statistically different at 0.05 level of probability. Although, after treatment application there were statistical differences of $\mathrm{Al}$ values in the $0-5 \mathrm{~cm}$ layer and the $20-40 \mathrm{~cm}$ layer when using the Tukey test at 0.05 probability level. However, $\mathrm{Al}$ concentration reduced at all layers (Figure 4A) corroborating results obtained by Bosco et al. (2008), who observed a decrease in aluminum concentration in the 0-30 and $30-60 \mathrm{~cm}$ layers when applying SW. For the second season as compared to the first, Al concentration in soil increased, 0.177 $\mathrm{cmol}_{\mathrm{c}} \mathrm{dm}^{-3}$, which is consistent with soil $\mathrm{pH}$ reduction from the first to the second season. Nevertheless, $\mathrm{Al}$ contents are not a limiting factor to the plant.

The soil $\mathrm{K}$ values presented differences with treatment application in the first season as shown in Figure 5B. The K mean value in soil was $0.222 \mathrm{cmol}_{\mathrm{c}} \mathrm{dm}^{-3}$ and after SW application its mean value decreased to $0.122 \mathrm{cmol}_{\mathrm{c}} \mathrm{dm}^{-3}$ (Table 5).

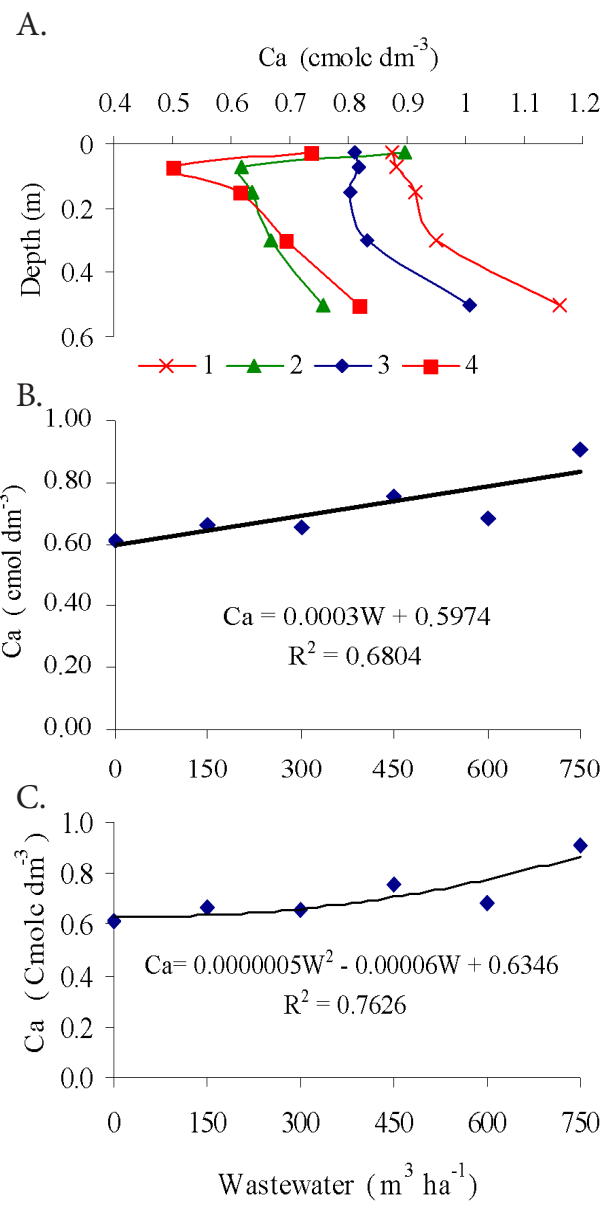

1 and 2 before planting and after harvest, first season. 3 and 4 before planting and after harvest, second season.

Figure 3. Ca concentration values in soil as a function of depth (A) and as a function of the swine wastewater rate for the first season (B) and second season (C)

Table 4. Mean values of $\mathrm{Al}$ in soil for both seasons

\begin{tabular}{|c|c|c|}
\hline Season & Collecting season & $\mathrm{Al}\left(\mathrm{cmol}_{\mathrm{c}} \mathrm{dm}^{-3}\right)$ \\
\hline 2 & After harvest & $0.178 \quad \mathrm{a}$ \\
\hline 2 & Before planting & 0.165 \\
\hline 1 & Before planting & 0.078 \\
\hline 1 & After harvest & 0.039 \\
\hline
\end{tabular}

Table 5. Mean values of $\mathrm{K}$ in soil for both seasons

\begin{tabular}{cccc}
\hline Season & Collecting season & $\mathbf{K}\left(\mathbf{c m o l}_{\mathbf{C}} \mathbf{~ d m}^{-3}\right)$ \\
1 & Before planting & 0.222 & $\mathrm{~A}$ \\
1 & After harvest & 0.122 & $\mathrm{~B}$ \\
2 & Before planting & 0.086 & $\mathrm{C}$ \\
2 & After harvest & 0.061 & $\mathrm{D}$ \\
\hline
\end{tabular}

The regression analysis was significant at 0.05 probability level and the behavior of $\mathrm{K}$ concentration values in soil with applied SW rates was quadratic reaching minimum point at the rate of $450 \mathrm{~m}^{3} \mathrm{ha}^{-1}$ as given by Figure $5 \mathrm{~B}$. However, the $\mathrm{K}$ values in the soil profile prior to treatment application did not show statistical differences at 0.05 probability for the second season (Figure 5C).

The soil K values before and after the second SW application presented statistical differences. While the $\mathrm{K}$ mean value in soil before the second SW application was $0.086 \mathrm{cmol} \mathrm{dm}_{c}^{-3}$ after 
A. Al $\left(\mathrm{cmol} \mathrm{dm}^{-3}\right)$
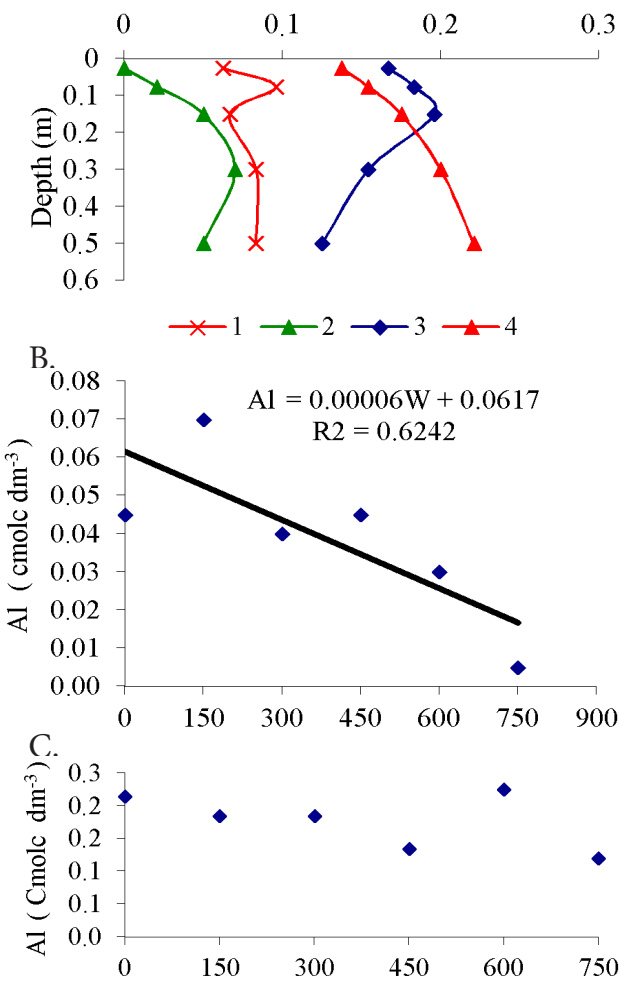

Wastewater $\left(\mathrm{m}^{3} \mathrm{ha}^{-1}\right)$

1 and 2 before planting and after harvest, first season. 3 and 4 before planting and after harvest, second season.

Figure 4. Aluminum concentration values in soil as a function of depth (A) and as a function of swine wastewater rate for the first season (B) and the second season (C)

the application it changed to $0.061 \mathrm{cmol}_{\mathrm{c}} \mathrm{dm}^{-3}$, which was lower than that obtained in the first season (Table 5). These results differ from those obtained by Freitas et al. (2004), who found an increase in $\mathrm{K}$ concentration in the $0-50 \mathrm{~cm}$ soil layer from $0.013 \mathrm{cmol}_{c} \mathrm{dm}^{-3}$ to $0.366 \mathrm{cmol}_{c} \mathrm{dm}^{-3}$ when applying SW.

The decrease in potassium contents after the first and second application is possibly associated to the imbalance source/drain with greater removal by the plant than that added by SW for both seasons. An aspect supporting this possibility is that swine wastewater K contents in the second application were lower than SW contents used in the first application (Table 1).

For phosphorus in the first season, the regression analysis was significant at the level of 0.05 and adjusted to the linear model (Figure 6B). Phosphorus values in soil increased as due to the $\mathrm{SW}$ application. P mean value prior to treatment application was $8.49 \mathrm{mg} \mathrm{dm}^{-3}$ and $14.17 \mathrm{mg} \mathrm{dm}^{-3}$ after it (Table 6).

The results found in this study are in accordance with Berwanger et al. (2008), who reported an increase in soil phosphorus concentration as a result of applying SW. Similar behavior was observed by Queiroz et al. (2004), who found an increase in available $\mathrm{P}$ content in relation to the initial condition with SW application indicating the accumulation of such macronutrient in soil. Ceretta et al. (2003) also observed that available $\mathrm{P}$ in soil increased considerably when applying SW over time.
A.
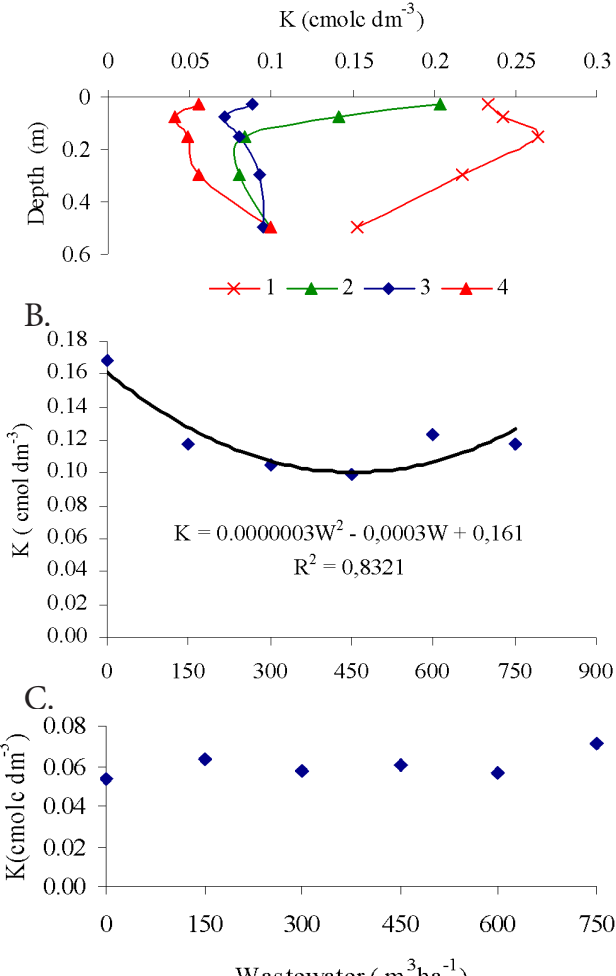

1 and 2 before planting and after harvest, first season. 3 and 4 before planting and after harvest, second season.

Figure 5. Potassium concentration values in soil as a function of depth (A) and as a function of swine wastewater rate for the first season (B) and for the second season (C)

A.
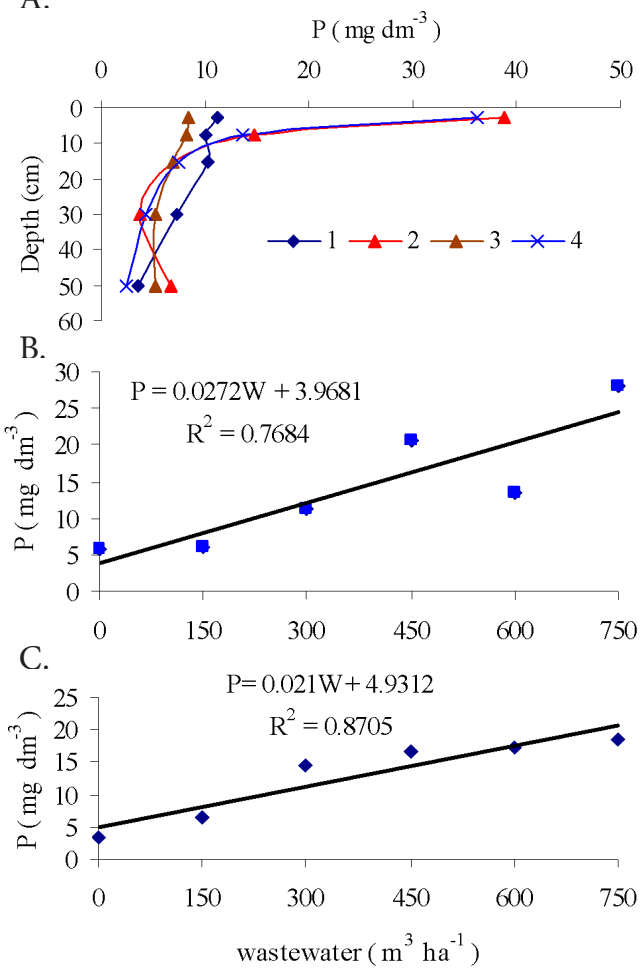

1 and 2 before planting and after harvest, first season. 3 and 4 before planting and after harvest, second season.

Figure 6. Phosphorus concentration values in soil as a function of depth (A) and as a function of swine wastewater rate for the first season (B) and for the second season (C) 
Table 6. Mean values of phosphorus in soil for both seasons

\begin{tabular}{cccc}
\hline Season & Collecting season & \multicolumn{2}{c}{$\mathbf{P}\left(\mathbf{m g ~ d m}^{\mathbf{3}}\right)$} \\
1 & After harvest & 14.17 & $\mathrm{~A}$ \\
2 & After harvest & 12.80 & $\mathrm{AB}$ \\
1 & Before planting & 8.49 & $\mathrm{BC}$ \\
2 & Before planting & 6.82 & $\mathrm{C}$ \\
\hline
\end{tabular}

For the second season, the $\mathrm{P}$ mean value prior to SW application was $6.82 \mathrm{mg} \mathrm{dm}^{-3}$ and $12.80 \mathrm{mg} \mathrm{dm}^{-3}$ after applying treatments (Table 6). The soil phosphorus concentration decreased in the second season when compared to the first, which was statistically significant at 0.05 probability by the Tukey test.

After SW application the P values differed statistically in the $0-5 \mathrm{~cm}$ layer, which was statistically different from the other layers when utilizing the Tukey test at 0.05 probability (Figure 6A). Also, 5-10 cm layer differed from the 20-40 and 40-60 cm layers. However, there was an increase in phosphorus concentration after treatment application. $\mathrm{P}$ as depicted in Figure $6 \mathrm{~B}$, the $\mathrm{P}$ values in soil increased after SW application.

These results are similar to those found by Freitas et al. (2004), who reported an increase in phosphorus concentration in the $0-50 \mathrm{~cm}$ layer from $0.4 \mathrm{mg} \mathrm{dm}^{-3}$ before application to $115.0 \mathrm{mg} \mathrm{dm}^{-3}$ after applying SW to soil.

Carbon values did not vary as a result of SW rates (Figure 7). The carbon mean value in soil was $4.78 \mathrm{~g} \mathrm{dm}^{-3}$ prior to application and $4.48 \mathrm{~g} \mathrm{dm}^{-3}$ after it (Table 7) and the carbon values in the soil profile before treatment application did not show statistical differences at 0.05 probability.

Ceretta et al. (2003) also reported similar results when working with applying liquid manure to pastures. The authors

$$
\text { A. }
$$
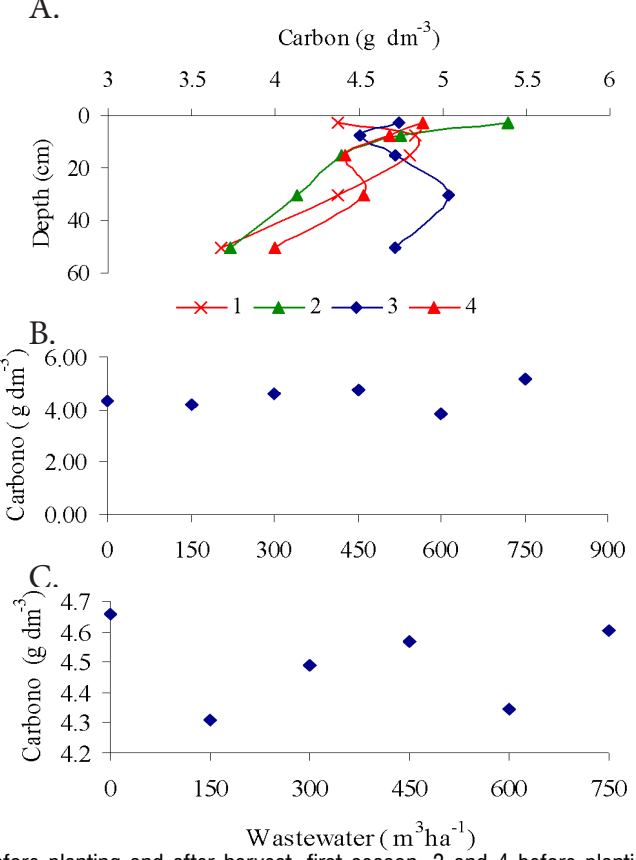

1 and 2 before planting and after harvest, first season. 3 and 4 before planting and after harvest, second season.

Figure 7. Carbon concentration values in soil as a function of depth (A) and as a function of swine wastewater rate for the first season (B) and for the second season (C)
Table 7. Mean values of carbon in soil for both seasons

\begin{tabular}{clcc}
\hline Season & \multicolumn{1}{c}{ Collecting season } & \multicolumn{2}{c}{$\mathbf{C}\left(\mathbf{g ~ d ~ d ~}^{-3}\right)$} \\
2 & Before planting & 4.782 & $\mathrm{~A}$ \\
2 & After harvest & 4.496 & $\mathrm{~A}$ \\
1 & Before planting & 4.495 & $\mathrm{~A}$ \\
1 & After harvest & 4.482 & $\mathrm{~A}$ \\
\hline
\end{tabular}

did not observe increases in soil organic carbon content after 48 months of successive applications. On the other hand, Andrade et al. (2005) and Guedes et al. (2006) observed a decrease in organic matter and organic carbon contents after a year of adding biosolids to eucalyptus crop. Such decrease, according to the authors, occurred due to the priming effect of carbon, which is the carbon reduction in soil after the input of organic matter in the area.

Ellerbrock et al. (1999) did not find alteration in the total content of $\mathrm{C}$ in soil either. This could be explained by the low contents of manure dry matter or by the characteristics of the carbon from swine liquid manure, rich in polysaccharides, protein, lipids, and other compounds that are thought to be easily degraded.

A different result was obtained by Cavallet et al. (2006), who evaluated the fertilizer value of wastewater from an enzyme industry in a Red-Yellow Argisol grown with corn. The authors observed that the organic carbon concentration decreased for all treatments in a five-month interval from the beginning to the end of the experiment. This reduction is common in agricultural soils because of the organic matter biodegradation as a result of several factors mainly cultivation, which promotes greater aeration and hence higher microbial activity.

\section{Conclusions}

1. Although the soil acidity had a slight increase, the soil $\mathrm{pH}$ did not present significant differences for both application seasons.

2. Phosphorus contents after harvest were higher than those observed prior to planting (SW application).

3. Soil K contents reduced with wastewater application as a function of the rates for both seasons.

4. The swine wastewater (SW) application contributed to phosphorus increase and aluminum reduction in soil for the first season and in the second season there were reductions in $\mathrm{K}, \mathrm{Ca}$, and $\mathrm{P}$ when compared to the first season. Therefore, applications did not contribute to the concentration increase of elements in the soil.

\section{Literature Cited}

Aguiar, M. I.; Lourenço, I. P.; Oliveira, T. S.; Lacerda, N. B. Perda de nutrientes por lixiviação em um Argissolo Acinzentado cultivado com meloeiro. Revista Brasileira de Engenharia Agrícola e Ambiental, v.10, p.811-819, 2006. 
Allen, R. G.; Pereira, L. S.; Smith, M.; Raes, D.; Wright, J. L. FAO56 dual crop coefficient method for estimating evaporation from soil and application extensions. Journal of Irrigation and Drainage Engineering, v.131, p.2-13, 2005.

Andrade, C. A.; Oliveira, C.; Cerri, C. C. Qualidade da matéria orgânica e estoques de carbono e nitrogênio em Latossolo tratado com biossólido e cultivado com eucalipto. Revista Brasileira de Ciência do Solo, v.29, p.803-816, 2005.

Barros, F. M.; Martinez, M. A.; Neves, J. C. L.; Matos, A. T.; Silva, D. D. Características químicas do solo influenciado pela adição de água residuária da suinocultura. Revista Brasileira de Engenharia Agrícola e Ambiental, v.9, suplemento, p.4751, 2005.

Berwanger A. L.; Ceretta, C. A.; Santos, D. R. Alterações no teor de fósforo no solo comaplicação de dejetos líquidos de suínos. Revista Brasileira de Ciência do Solo, v.32, p.25252532, 2008.

Bezerra, F. B.; Oliveira, M. A. L.; Perez, D. V.; Andrade, A. G.; Meneguelli, N. A. Lodo de esgoto em revegetação de área degradada. Pesquisa Agropecuária Brasileira, v.41, p.469476, 2006.

Bosco; T. C. dal; Iost, C.; Silva; L. N.; Carnellosi, C. F.; Ebert, D. C.; Schreiner; J. S.; Sampaio, S. C. Utilização de água residuária de suinocultura em propriedade agrícola - estudo de caso. Irriga, v.13, p.139-144, 2008.

Caovilla, F. A.; Sampaio, S. C.; Pereira, J. O.; Vilas-Boas, M. A.; Gomes. B. M.; Figueiredo, A. C. Lixiviação de nutrientes proveniente de águas residuárias em colunas de solo cultivado com soja. Revista Brasileira de Engenharia Agrícola e Ambiental, v.9, Suplemento, p.283-287, 2005.

Cavallet, L. E; Lucchesi, L. A. C.; Moraes, A; Shimidt, E; Perondi, M. A; Fonseca, R. A. Melhoria da fertilidade do solo decorrentes da adição de água residuária da indústria de enzimas. Revista Brasileira de Engenharia Agrícola e Ambiental, v.10, p.724-729, 2006.
Ceretta, C. A.; Durigon, R.; Basso, C. J.; Barcellos, L. A. R.; Vieira, F. C. B. Características químicas de solo sob aplicação de esterco líquido de suínos em pastagem natural. Pesquisa Agropecuária Brasileira, v.38, p.729-735, 2003.

Duarte, A. S.; Airoldi, R. P. S.; Folegatti, M. V.; Botrel, T. A.; Soares, T M. Efeitos da aplicação de efluente tratado no solo: $\mathrm{pH}$, matéria orgânica, fósforo e potássio RevistaBrasileira de Engenharia Agrícola e Ambiental, v.12, p.302-310, 2008.

Ellerbrock R. H.; Höhn A.; Rogasic, J. Functional analysis of soil organic matter as affected by long-term manurial treatment. European Journal of Soil Science, v.50, p.6571, 1999.

Freitas, W. S.; Oliveira, R. A.; Cencon, P. R.; Pinto, F. A.; Galvão, J. C. C. Efeito da aplicação de água residuária de suinocultura sobre a produção de milho para silagem. Revista brasileira de Engenharia Agrícola e Ambiental, v.8, p.120-125, 2004.

Guedes, M. C.; Andrade, C. A.; Pogianni, F.; Matiazzo, M. E. Propriedades químicas do solo e nutrição do eucalipto em função da aplicação do lodo de esgoto. Revista Brasileira de Ciência do Solo, v.30, p.267-280, 2006.

Melo, R. F.; Ferreira, P. A.; Matos, A. T.; Ruiz, H. A.; Oliveira, L. B. Deslocamento miscível de cátions básicos provenientes da água residuária de mandioca em colunas de solo. Revista Brasileira de Engenharia Agrícola e Ambiental, v.10, p.456465, 2006.

Queiroz, F. M.; Mattos, A. T.; Pereira, O. G.; Oliveira, R. A. Características químicas de solo submetidos ao tratamento com esterco líquido de suínos e cultivados com gramíneas forrageiras. Ciência Rural, v.34, p.14871492, 2004.

Smanhotto, A. Efeito da aplicação de água residuária de suinocultura em solo cultivado com soja. Botucatu: UNESP, 2008. 121p. Tese Doutorado 